\title{
OCCURRENCE OF INCLUSION BODIES IN THE GUARD CELLS OF THE STOMATA OF MOSAIC-TOBACCO PLANTS
}

\author{
Shigekatsu HIRAYAMA and Akira YUASA \\ (Tokugawa Institute for Biological Research, Tokyo) \\ Received December 25, 1936
}

Recently SHEFFIELD (1936) reported that inclusion bodies might occur in every cell over large areas of the epidermis of a plant affected by certain viruses, while they were not found at all in the guard cells of the stomata. According to her investigation, no plasmodesms could be shown to exist between the guard cells and the surrounding tissues, and it was suggested that the virus was therefore unable to reach the guard cells.

In 1923, however, MCKINNEY, ECKERSON and WEBB observed the intracellular bodies in the guard cells of leaf stomata in mottled

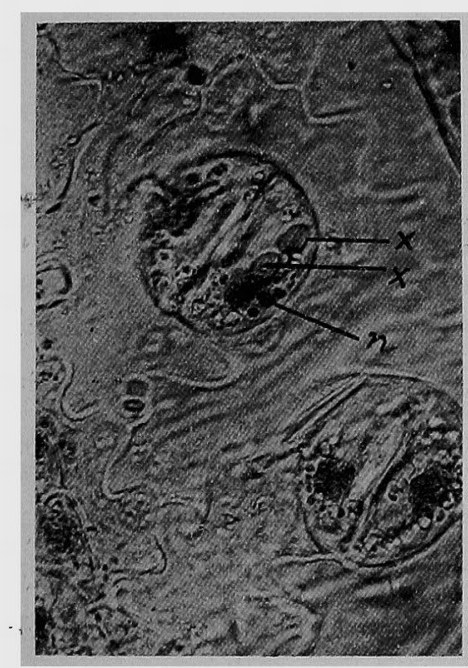

1

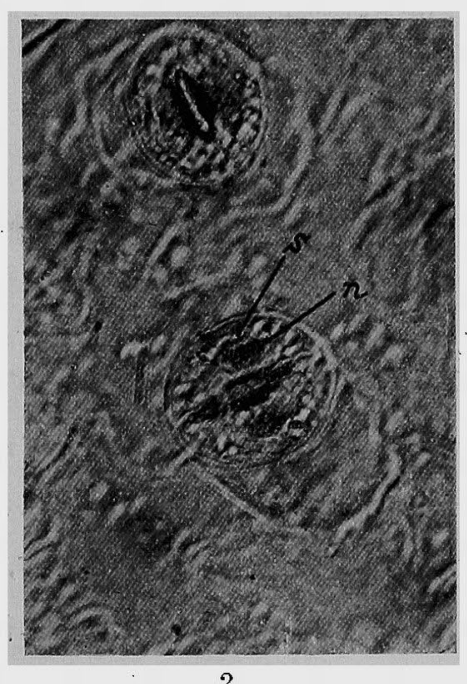

2

Photomicrographs 1-2.

Inclusion bodies are seen in the guard cells of stomata. $n$, nucleus; s, striate material; $x, X$-body. $(X$ ca. 400$)$.

Hirayama, S. and YuASA, A.: (1935) Ann. Phytopath. Soc. Japan, V, 197-205. MCKINNEY, H. H., Eckerson, S. H. and WEBB, R. W.: (1923) Jour. Agr. Res., XXVI, 605-608.

SHEFFIELd, F. M. L.: (1936) Ann. Appl. Biol., XXIII, 506-508. 
wheat plants. The present writers also reported in a previous paper (1935) that the X-bodies were proved to be present in the guard cells of the stomata of tobacco plants affected with mosaic virus. In the present work they carefully reexamined the materials and confirmed the previous results (Photos, 1, 2).

In their observation the writers used fresh materials and mounted in aceto-carmine, while SHEFFIELD made observation on materials which were fixed with CARNOY's fluid and treated by FEULGEN's nucleal-staining method and stained with orange $G$. So in the latter case a disintegration of the cell inclusions might occur during the course of cytological treatments. It was shown by the writers that the X-bodies became obscure after about one hour when the materials were treated with the aceto-carmine.

From the result of the writers' investigations, it may be concluded that inclusion bodies occur in the guard cells of the stomata, but that the acetic acid used in the fixation may however disintegrate or dissolve them.

モザイク病となつた煙草の氣孔の孔適細胞にも

異幣小體怡存在する 摘要)

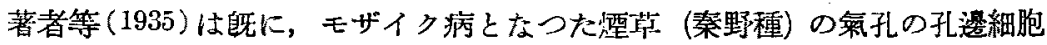
にも X-body 及びその他の異常小體の見られることを報じてが，最近 SHEFFIELD，F. M. L. (1936) は，モザイク病に㻏されを煙草の氣孔の孔邊細胞には 細胞內異常小體は存在しないと述べてるる。

そこで箸者等は再び同じ材料を誦へ，X-body 及び striate material 等が孔

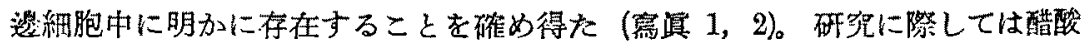
カーミン泎によつたが、これ等異常小體は醋酸によつて次第に侵されることも わかつた。 SHEFFIELD は CARNOY 夜で固定し, FEULGEN の核染色法とオレ ンデ G. とによる染色方法で頙察してるるから，その操作中に孔透絴胞の異常 小體は破壞されたものと想像される。 